\title{
APRESENTAÇÃO
}

\author{
Presentation
}

\section{PENSAR PLURAL}

\section{Plural Thinking}

Com satisfação, apresentamos o terceiro e último número da Teocomunicação para o ano de 2014, dentro da nova periodicidade assumida pela revista. Este número tem um perfil diversificado. Os artigos abordam temas variados: da hermenêutica bíblica à liturgia, passando pela experiência mística e religiosa. Assim, temos três focos: hermenêutica e exegese, liturgia, experiência do sobrenatural e da consciência moral.

Os três primeiros artigos abordam questões relacionadas com a hermenêutica e a exegese: Antônio Francisco Jacaúna Neto escreve sobre a parábola da vinha, conforme se encontra no texto de Mateus 20,1-16, fazendo uma hermenêutica sob a ótica da vocação e da missão; Marcos Eduardo Melo dos Santos faz uma exegese do capítulo 5 do livro do Exodo, buscando caracterizar os personagens nele presentes; Josué Soares Flores, orientado pelo Prof. Dr. Márcio Luís Fernandes, estuda a obra hermenêutica de Meister Eckhart a partir dos métodos exegéticos medievais e sua influência as gerações de místicos posteriores.

Outros dois artigos se ocupam com a liturgia: Vanderson de Souza Silva estabelece uma relação entre a liturgia e a espiritualidade, considerando a Lex orandi como fonte genuína de espiritualidade cristã; Thiago Aparecido Faccini Paro reflete sobre o espaço litúrgico, defendendo a posição de que sua disposição deve conduzir para o mistério ali celebrado.

Os dois seguintes artigos exploram o tema da experiência humana e religiosa, cada um a seu modo: Carlos Frederico Lauer Garcia reflete a relação entre a finitude da experiência humana e o desejo de um sentido

\begin{tabular}{|l|l|l|l|l|l|}
\hline Teocomunicação & Porto Alegre & v. 44 & n. 3 & p. 309-310 & set.-dez. 2014 \\
\hline
\end{tabular}


infinito a partir de Blaise Pascal e Viktor Frankl; Ivo Studart Pereira avalia a tese de Viktor sobre o caráter transcendente da consciência moral como argumento-chave para elucidar sua visão de experiência religiosa.

Pensar de forma plural é um desafio permanente em qualquer área da ciência humana, mas, de modo particular, na Teologia, pois ela sofre a tentação permanente de se fixar em um tipo determinado de reflexão e de posição. Ultrapassar a própria fronteira é um requisito indispensável para que a Teologia possa avançar nos dias de hoje e romper paradigmas até então considerados satisfatórios.

Geraldo Luiz Borges Hackmann

Editor 